\title{
Love In Action
}

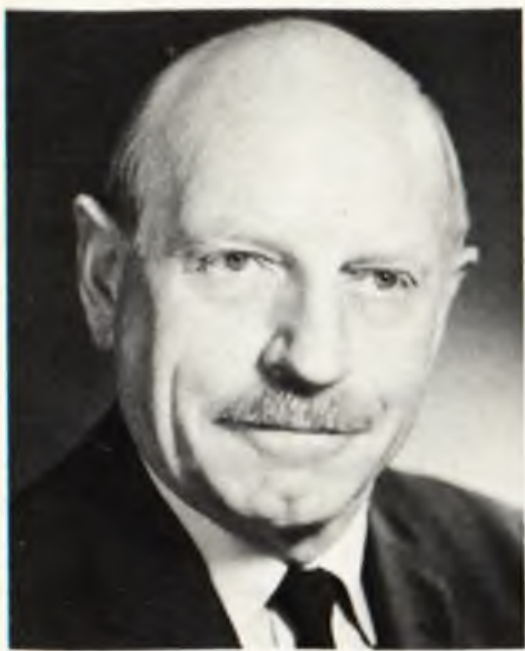

\author{
C. Sandy D'Oliveira \\ Executive Director, Operation Upgrade of Southern Africa.
}

\section{OPSOMMING}

In Augustus 1966 het mnr en mev D'Oliveira medestigters geword van Operation Upgrade of Southern Africa.

Vandag is die organisasie wat vier opleidingsentra oor die hele Suid-Afrika het, besig met 'n veldtog om ongeletterdheid oor die hele Republiek uit te wis - 'n veldtog wat die stigters oor die hele vasteland van Afrika wil voer om brûe van begrip en goedgesindheid tussen die Noorde en Suide en tussen Swart en Blank te bou. Ons in Suid-Afrika kan praktiese en Christelike leiding aan die wêreld gee om 'n praktiese en besonder waardevolle bydrae aan sowel Suid-Afrika as alle nasies van die vasteland gee.

Die skrywer hoop dat hierdie en ander programme aanmerklik sal bydra tot die vordering wat plaasvind deur mans en vroue te help om uit die beslotenheid van ongeletterdheid, lae lewenspeil, honger, siekte, hoë geboortesyfer en ... toenemende aantal ongeletterdes weg te breek.

$T$ was a cold winter's night on a lonely mission in I Pondoland. Alone with my thoughts I sat before my makeshift fireplace. I had just set light to the half-green wood through the paper and kindling placed beneath it. I was intrigued to see how the curled, broken fibres of the wood straightened out as they were caught in the ascending draughts of warm air fleeing before the strengthening flames from below. Then, as the temperature rose above a certain point, they glowed at the tips like brilliant stars shining through the stormw rack of clouds seeking to obscure them. It was an intermittent glow, fading out as the upward draught of hot air veered off on another course, then glowing again as it returned. This continued until each piece of firewood caught light in its turn; imparting this glow to others as they, in their own fiery refining, became translated from the coarseness of their solid material form into dancing flames, and giving form and expression to the thoughts welling up within me as I sat entrancedly gazing into them.

Almost fifty years ago a light was kindled in the heart and mind of an American missionary working without much success among the wild Moro people of the Philippine Is- lands. He saw, with a vividness never before experienced, that his approach to these people - human beings like himself - had been that of one condescendingly prepared to give to those he considered ignorant savages certain of the benefits of his civilisation and culture. His whole approach to them altered. He sought to learn Maranaw, the language spoken by them. He found that Maranaw had never been reduced to writing, so he wrote down the sounds of the language in the Roman alphabet, with only one sound for each letter. In six weeks his list contained 1300 words, and he found that his interest had grown just as rapidly. With his helpers he devised a simple teaching chart that was based on three common words containing all twelve consonants of the Maranaw language. Through combining these twelve letters with the four vowels of Maranaw, one could soon learn to read all the forty-eight words on Chart One. It was not long before a newspaper, the "Lanao Progress" was being printed in English and Maranaw. In this manner was opened the door to a literacy campaign that has spread around the world. Born in love and concern for the lesser-privileged, whose eyes could now be opened to an innate potential they 
had never realised they possessed, and who had therefore been condemned to walk in the darkness of ignorance from the cradle to the grave, literacy brings both light and the warmth of love into the lives of such as these. Dr Frank C Laubach is the name of this missionary. Because of him, millions have been given the opportunity to recognise and develop that potential so long stifled and bound by the bonds of illiteracy. Also, because of his dedicated example, hundreds of thousands of men and women throughout the world are initiating literacy programmes as they too were touched by the fire of this man's inspiration.

One of those thus inspired by Dr Frank Laubach was Louise Morrill. Her early childhood years were spent with her parents in Stanley Hall, the Louisiana residence of Henry Morton Stanley the journalist who, late in the 19th century, went to Africa in search of David Livingstone. In her book "Across Africa and Halfway Back" she wrote: "It was here (in Stanley Hall) that I became interested in the people of Africa. Because I had not found a way to express it, I had long felt frustrated. Frank Laubach, through his writings, and later in talks that I heard, rekindled this flame that, through the years, had been reduced to a dim flicker.',

Through the personal training, and the inspiration received from Dr Frank Laubach, that "dim flicker"' strengthened and eventually became her guiding light to the dark continent of Africa. In travels compassing twenty-six countries in Africa, her most outstanding was the one she took across the heart of Africa, a trip never before undertaken by a woman. She set off from Dar-es-Salaam in 1960 in a secondhand Volkswagen Beetle en route to Douala on the West Coast of Africa, visiting many areas in between, training missionaries in the techniques of teaching adult illiterates, helping them strike off the shackles of illiteracy, and opening the way to the rewarding development of their potential. In so doing gratitude and goodwill were generated wherever she went, and the work of missionaries made that much easier.

Later that year, having safely come through the first Congolese rebellion, she came to South Africa. There she kindled that same "flame of inspiration" in the hearts of many others, including myself. The first day I saw her I knew, beyond any doubt whatsoever, that this was the woman I had been waiting for all my life. At the request of Dr Frank Laubach she had come to visit the mission hospital of which I was administrator. That night she spoke to the assembled staff of her work among the adult illiterates of the world and, as she spoke, there came to me an understanding of a vision I had been given some time before. In this vision I had seen myself in a narrow sidestreet paved with cobblestones, and bounded on either side by high old buildings that cut off the light, and made it impossible to see clearly. I could, however, faintly discern the outline of a figure, kneeling amid all the filth of a gutter set in the middle of the street. His whole posture spoke to me of one destitute of hope, one who knelt in the ultimate degradation of the gutter. Then, as I watched, the dull drabness of that alleyway glowed as a Light not of this world shone upon this man. In the corner of his eye I was able to see, for the first time, a teardrop slowly growing bigger. Then, before it could fall into the filth of the gutter beneath, I saw the source of the radiance. It came from one side, and with it I saw a Finger outstretched towards the man, not in condemnation, but lovingly to touch and detach that teardrop from where it hung quivering. This teardrop, then, with the glorious Light of the Love of God behind it, was held before my eyes that I might see for myself a world of beauty and colour, compassed about in that symbol of man's complete hopelessness . . . a tear. And, as I looked, there grew within me the wondrous certainty that no one is beyond the Power of His Love: that, no matter how degraded, how hopeless, how steeped in sin we are, He can take that symbol of our degradation, our hopelessness, our sinfulness, and from it create beauty such as we can never imagine. I knew, as I listened to Louise telling us of the hopelessness of the illiterate, that the man I had seen in the gutter was none other than the man of whom she spoke.

Louise and I were married in July of 1966 and, two weeks later, launched Operation Upgrade of Southern Africa. Today this organisation, with four training centres throughout South Africa, is engaged in a campaign dedicated to the eradication of illiteracy throughout the Republic; a campaign we seek to extend throughout the continent of Africa in order to build bridges of understanding and goodwill between the North and the South, and between Black and White. We, in South Africa. can give to the world a practical and Christian lead, and make a practical and immensely valuable contribution both to South Africa and all other nations of this continent.

I believe, in clarification of the above, that a practical illustration be given. In March 1971, at a meeting I addressed in Johannesburg, I was challenged to prove my statement that illiterate patients in a TB Hospital could be brought to a Standard Four literacy level within three weeks. My challenger, a Rotarian, told me he was very interested in the paraplegic patients in Baragwanath Hospital, and challenged me to make them literate in three weeks. I accepted the challenge, asked him to pick out ten Zulu-speaking paraplegic patients who had never been to school or learnt to read and write.

Within a few weeks, with the willing co-operation of the medical authorities at Baragwanath, arrangements were made for the start of a training course there. Classes were held from 9 a.m. to 11.30 a.m., and from 2 p.m. to 4 p.m. daily, except Saturdays and Sundays. Within thirteen days these men were able to write an examination set at a Standard Four literacy level. Everyone passed. The lowest mark was $55 \%$ and the highest $92 \%$. What was even more impressive, however, was the psychological impact on these men. Immediately prior to this these men had all been in a state of deep depression; each withdrawn into his own private hell of hopelessness and despair, having been harshly precipitated into a reality with which they were unequipped to cope. This was confirmed for me by the resident clinical psychologist, Mr Mangani, who told me that he had never before witnessed 
so sudden and dramatic change for the better as he had seen in these men after they had participated in the literacy classes.

One of these ten paraplegics was thirty-five year old Ben Mathimbe, from the Mukaro Mission in Rhodesia. He was a painter in Johannesburg when he was attacked and heavily struck between the shoulder blades. He was taken to Baragwanath Hospital, where he was found to have a fractured spine. His legs were paralysed. He was paraplegic, and confined to his wheelchair or his bed. With this great handicap he had another which, until then, he had not fully appreciated ... he was illiterate. With his hopes and plans for the future shattered, Ben showed little interest in attempts at rehabilitation, and had little incentive. What followed his becoming literate is best told in the words of the occupational therapist who worked with Ben, and wrote as follows: "In 1971 Operation Upgrade came to Baragwanath and provided Ben with an opportunity which gave him the encouragement he needed, and a glimpse of what could still be achieved by him. With the hope this encouragement gave him he once again took up the struggle, and he is slowly becoming more and more involved in the rehabilitation programme. To those of us who are aware of what the word 'paraplegic' means, this indeed shows much courage, and deserves admiration. He is now learning to type, something which he could not have done had he not learnt to read and write. He is also thinking about learning machine-knitting and/or leather work in order to earn a living at home once he is discharged from hospital. In other words, Ben has once more become an individual with a will to live and achieve."

Miss Iris Röscher, Head of Nursing Services (Psychiatric), whose wholehearted and warm dedication are known to many, was the initiator of a unique experiment held at the Weskoppies Psychiatric Rehabilitation Centre in 1974. After only four weeks twelve illiterate patients, taught an hour a day by an Operation Upgrade teacher, successfully wrote an examination at a Standard Four literacy level. It may not seem possible but it is, nevertheless, a matter of record that these illiterate patients were brought from illiteracy to a Standard Four literacy level in twenty hours. A Department of Health official, commenting on this unique experiment, said: "It is, perhaps, a bit premature to determine to what extent this newfound ability contributes to the total rehabilitation of the patient. There is no doubt however, though, that it can be most valuable in the normal rehabilitative measures employed in the care of the patient."

As a result of this experiment eight candidates from Weskoppies and Sterkfontein Hospitals were trained as teachers of illiterates by Operation Upgrade of Southern Africa in January 1976. I am informed that our literacy methods now form part of the rehabilitation programme for patients who "benefit therapeutically from the course." Another important aspect of the programme is that it enables the patients to communicate directly with their families.

A most important aspect of our programme is the provision of reading material, written to the reading level of the new literate, that enables him to retain his ability to read through practice. Booklets on subjects that the adult finds both interesting and informative are researched, written and published by Operation Upgrade for this very purpose. These publications are heavily subsidised by us in order to keep them at a price easily afforded by the newly literate.

It is essential however, in areas where modern medical technology is to be introduced - as in a health education programme - that both the scientific and the cultural aspects be reconciled in such manner that cultural integrity is preserved and enhanced without sacrificing scientific accuracy.

Simple stories, based on real-life situations, and one or other aspect of the cultural heritage, can be used to bring about an understanding of new principles and ensure that, through practice, they become a living and integral part of their daily activities.

The Zulu, for instance, looks almost with horror on any abuse of hospitality, and use is made of this in my story "Good Seed and Bad Seed" to emphasise for the newly literate tuberculotic how, even though unconsciously, he may be guilty of a serious breach of custom as a result of absconding from hospital.

\section{GOOD SEED AND BAD SEED}

The nurse looked around the ward. "Good-night," she said as she put out the lights. Magwaza waited until she had left. It was dark. Silently he stole from his bed. He reached into his locker for his clothes and dressed quietly. Magwaza had been in the hospital four months as a tuberculosis patient.

Tuberculosis is a disease of the lungs. Tuberculosis can cause a man to die if not treated properly. The inyanga says it is the idliso that causes tuberculosis. The inyanga cannot cure tuberculosis.

Magwaza spoke silently to himself: " Why must I listen to the Doctor and stay here longer? Does he not know it is time for the ploughing of the land? Does he think my wife Thandile can handle the plough? No, I cannot lie here, I must go."

After two days Magwaza came to the kraal of Mpisi. "Sakubona mnumzana. I seek a resting place for to-night. I go to my home near Gingindhlovu. I have travelled far and I am tired."

"'You are welcome, friend," replied Mpisi. "You will eat with me and tell me your news." They sat down in the hut of Mpisi. After eating they drank beer and smoked their pipes. They spat on the ground from time to time. They spat to clear their throats. When Magwaza was in hospital he spat into a cup. The nurses in the hospital stopped him when he spat on the floor. He spat now where he liked, thought Magwaza.

In the morning Magwaza thanked the Headman and left. What he had spat on the ground remained. It dried and became one with the dust. The winds played around the hut of Mpisi; they reached into the hut. The winds threw the dust into the air. The children played in the wind. They opened their mouths to shout and laugh. The dust entered their mouths and lungs. They did not feel it. They still laughed and shouted. Time passed ... the children laughed no more. They grew thin. They spat blood. 
Magwaza had ploughed his lands. He had planted his seeds. The seeds were growing: the good seeds grew in his lands, the bad seeds grew in the children . . .

Here in South Africa 1979 has been declared Health Year. The Department of Health, recognising the need to involve as many sections of the population as possible, has published a booklet on many different diseases in the different African languages. These booklets, written in a controlled vocabulary, can easily be read and understood by the newly literate. By this means a far greater dissemination of health education material will be made possible.

It has long been the writer's belief that the objects of the Departments of Health and Agriculture in the different Homelands could more readily be achieved, and closer cooperative participation given by the rural population through an adjuvant literacy programme. With the willing cooperation of Chief Lucas Mangope, his Cabinet, and officials of their Departments of Health and Agriculture, a teacher training course was held in the Taung Agricultural College. Health Educators and Agricultural Extension Officers were given a one week's training course by an Operation Upgrade team. All candidates participating were most enthusiastic for they soon realised that, through giving to the people among whom they worked, the gift of literacy, they would receive from them a wholehearted co-operation. In addition, their lectures can now be reinforced through the provision of booklets on these subjects, written to the reading level of these men and women in their mother tongue. Even when these lecturers move on to other areas, the valuable information dispensed by them on basic health education and good farming practices will live on in these booklets.
It is my hope that this, and other programmes, will add appreciably to the progress being made in helping men and women to break out of the closed cycle of illiteracy, low living levels, hunger, disease, high birthrate and ... increasing numbers of illiterates.

The late Dr Albert Schweitzer once said: "The tragedy of life is that which dies in a man while he still lives." Many and diverse are the unrevealed and unrecognised talents that quietly die in men and women daily condemned to the drudgery of an unrewarding sameness; a monotony imposed by an inhibiting illiteracy that, like a modem Black Hole of Calcutta, imprisons and hides those talents from an unknowing and uncaring world

The Weskoppies patients, maybe laughed at and scorned by their neighbours because of their former mental instability, will be greeted with respect on their return, for they are now possessed of an ability lacking in those who laughed at them. However, because our literacy programme is based on love, and the method of teaching so simple that the former illiterate is able to teach others, they will be able to heap - in love - coals of fire on the heads of their former detractors. In this way the dry tinder of those lives will inevitably catch light and perpetuate that flame handed on to so many others by Dr Frank Laubach before he was called to his reward . . . a flame that as true "love in action" will kindle in the hearts of many others a like inspiration and dedication to the service of others.

In Corinthians 13: 7-8 (Phillips' translation) we read: "Love knows no limit to its endurance, no end to its trust, no fading of its hope; it can outlast anything. It is, in fact, the one thing that still stands when all else has fallen." 